DOI https://doi.org/10.18551/rjoas.2016-12.28

\title{
THE ECONOMIC VALUE OF HOUSEWORK AND ITS CONTRIBUTION TO HOUSEHOLD INCOME
}

\author{
Febrianty ${ }^{*}$ \\ Politeknik PalComTech, Indonesia \\ Tarmizi Nurlina, Syamsurijal, Sariman Tatang A.M. \\ University of Sriwijaya, Indonesia \\ *Email: febrianty@palcomtech.ac.id
}

\begin{abstract}
The different number of production and consumption of goods and services by household is one of the causes of inequality and imbalance of income inter-households. This research aims to look at the condition of economic value of household income that is looked from the wife's income and look at the factors that influence the amount of household income. The research sample uses all households in 9 sub-districts in Palembang city. The results showed that wives who have toddler can give a higher economic value to the household income are compared with wives who do not have toddler. Other results of this research showed that the age of husband and wife as well as the number of family members have an effect on household income.
\end{abstract}

\section{KEY WORDS}

Economic value, household income, family income, inequality.

The different number of production and consumption of goods and services by household is one of the causes of inequality and imbalance of inter-households income. Based on the classical economic theory, namely The New Household Economy explaining that household hold activities to produce goods and services at the same time is considered as well as users of goods and services.

Household production is an activity of non-market to produce goods or services for personal consumption by using a combination of capital and labor itself, or in other words, a household can produce goods and services that can be consumed by the household without having to spend capital (Ironmonger, 2001; Pylkkanen, 2002). Goods or services of household, such as: Organizing of house and yard, meal preparation, washing clothes or taking care of children, resulting from the implementation of a number of jobs in the household (Robeyns, 2000).

Estimates of how much production of household that is able to contribute to the total production of goods and services in the economy must be calculated indirectly. Household production of is a part that presents an important area for research. First, household production is the main component of daily life for most people. Second, household production is a significant source of economic activity and is directly linked to living standards.

According to several studies conducted by Herbert H. Clark, Gregory L. Murphy. (1982), Robeyns (2000) as well as Champ et al (2003) argue that household work should be judged worth, both economically and psychologically. Economically, housework can contribute substantial national income, which is about 9 percent-35,6 percent of GNP, in other words, housework is considered to have a value that is able to increase national income.

While psychologically, shown from the research results of Donald and Hammermesh (2009), who found that the worker involved in the household production can afford to sacrifice their free time is lower than with formal workers who work in the office. 
Franzis and Jay Stewart (2009) calculate the size of the extended income or extra income including estimated production households with income. The study's finding indicates that household production can contribute between a quarter and a third of total of extended income, the finding else shows that the extended income is more spread evenly than income even if the household production and income are positively correlated. The different results of research conducted Jenkins and O'Leary (1996) suggest that there is a weak correlation between household production and income. Zick et.al (2008) conducted a similar analysis and found that the household production is able to reduce the size of the economic imbalance when it is included together with income or in other words, household which is able to produce goods and services for consumption can reduce their inequality household income.

The production model of household developed in Gronau's research (1986) estimates that high-wage workers will spend less time on work of non market than low-wage workers (with the assumption that all individuals have preferences of identical and equally productive in the work of non-market), This model can easily be generalized to two people with the assumption that households where husband and wife maximize the functions of public utilities. Worker with high wage spends less time in household production activities rather than low-wage worker, and individual with a partner who has a high wage spends less time to do housework than people whose partner has low wages.

Two basic approaches are commonly used in assessing the household production i.e. emphasizing the opportunity cost of time that is spent on household production (using a combination of its own capital and labor that is unpaid) and assigning a value to the production as income that an individual can produce in market. In addition, household production can also be measured from the services purchased through the market and assessing the activities of household as the cost of hiring someone to do household duties (Gronau, 1977; Murphy, 1978; Ironmonger, 2001; Pylkkanen, 2002).

Another method that can be used in the assessment of household production activities is by assessing the time that is spent to produce goods and services for households based on the average market wage per hour of a professional doing the same activities. Market replacement cost is the cost of expert or professional who enter the labor market. Market replacement cost uses wage of paid worker who produces the same services in market (Gauger \& Walker, 1980; Zick \& Bryant, 1983; Juster and Stafford, 1985; Arboleda, 1999; Pylkkanen, 2002; Couprie, 2002).

Gronau (1977) also states that with increasing number of children for other activities use will reduce one's leisure time, because children are intensive goods better than other activities. For example, a person who works on four activities of housework before childbirth, she get one additional free time and work market or a little time for housework, but after childbirth, time would have been entirely used for activities related to child care. Activity effect related with children on homework and market work is highly dependent on the profitability of home production. Women as wife is generally offered with a lower wage level than her husband and possibly more productive at home. Therefore, efficient for woman to produce the goods home. When women work, with increasing number of children, her services in market sectors will be reallocated to housework, while for women who does not work her leisure will be reduced and housework increases. The greater the age of child in the home the possibility of participation of women in the labor market is getting higher and less time at home.

The age factor of couples can also determine their participation in housework. Older people have a tendency to stay at home more than younger couples. People with older age usually like a dinner guest's visit to the house whether relatives or close friends, therefor it is assumed work at house will increase. But in another couple with a younger age, the possibilities for eating out habits increases that in variety have a negative effect on the time spent at home. This is because one of the pair being older so that the possibility of participation in housework increases continually, and reaches a maximum and then decreases. According to Green (2003), Age means, as continuous variable is expected to have a positive effect and subsequent negative effects on housework. 
Most households with a larger number of members, housework that is done less than household with smaller members, if the home as a their domicile have a large size. The larger the house the more work that must be done in the house, because the amount of room to do more and more that housework is also increasing, and ultimately it has a negative correlation with the number of household members. Based on the background described, then the housework can be an interesting theme to be used as a research to look at the economic value generated by wife as homemaker and to look at the factors that may affect the economic value of housework.

Thus, this study aims to investigate (1) how much the economic value of housework generated wife in Palembang city is, and (2) the effect of characteristics of households (wife's age, husband's age, number of family members, wife's education and husband's education) on the economic value of housework on household income.

\section{LITERATURE REVIEW}

Household Production Approach. Household production approach seen as complementary of micro-economic framework is appropriate to analyze the time allocation in the family. Time allocation method is the most appropriate method to describe the various activities, most often for works are not paid and are not recorded as economic activity published. Time among various activities is allocated to market work and housework and or leisure. According to Bennett (1983), the time is useful for generating: 1) the production of services in the household such as cooking, cleaning and organizing the house, washing and ironing clothes, 2) production of wage or salary of market work that generates income, and 3) the production of subsistence foods and other items that are not paid in a peasant family with a separate income.

Work at home and market work subtitute perfectly, i.e. one same satisfaction derived from consuming goods or services, whether bought on the market or produced at home. According to Pylkkanen (2002), if a person enjoys utility directly from production activities, the portion of time spent on home production set on as leisure. Generally in the household production model, household maximizes utility of the specific constraints problem with considering technology and resources. Rochaeni and Lokollo (2005) citate theory of Becker (1965), which states that household in producing the output combine capital goods and raw materials, labor, and time. Utility (satisfaction) obtained directly through the consumption of a variety of household final goods.

Household derives satisfaction from a combination of several things, namely: goods and services purchased in the market or so-called market goods (denoted by $\mathrm{C}$ ), goods and services produced by household or so-called home goods (denoted with G), and leisure that is had by individual in household with one or more household members have the opportunity to work in the labor market (denoted by $L$ ). Preferences of the households with a combined $C, G$, and $L$ can be written as follows:

$$
U=u(C, G, L)
$$

Bryant (1990) assumes that market goods and home goods, C and G, as perfect substitutes. It is used to simplify three-dimensional graph of $G, C$, and $L$ combination to be two-dimensional combinations so it is easy to understand. The equation can be written as follow:

$$
U=u(C+G, L)
$$

Decision Theory to Work. According to Ehrenberg and Smith (2000), the decision to work finally is a decision about how to spend time. One way to use the available time is spending in a fun recreational activity. Another way in which a person uses the time to work, i.e., work at home, doing household production such as: taking care of the children, sewing, 
meal preparation, and etc. Instead, someone can work with paid and someone uses the income to buy food, domicile, clothing, and child care. Not work.

According to Tarmizi (2012), there are some characteristics that cause a person to work. First, one has non-labor income. This is caused by the low wage, the choice of working or not working is the same choice. For example, on the condition women will choose not to work, because time which is sacrificed for the work is not comparable with the income. Second, when faced with the high wage level so one will choose to work. When the MRS (Marginal Rate of Substitution) of rest on income is high, means the individual will sacrificy her rest to earn more income, therefore, she will choose to enter the labor market.

Household Production Model. The household production model typically utilize welfare function consisting of: buying in the market, and producing goods at home, as well as leisure component. Utility function is then maximized, submission on the constraint function of budget, time, and household production. Marginal productivity of goods of household production is estimated then this estimation is used to calculate the value of household production.

Illustration of the processes applied to assess the household production and is based on Gronau (1980), Heckman (1974) and Becker (1965). Assumed that the utility function is as follows:

$$
U=U(X, L h, L w)
$$

where: $U$ = welfare; $X=$ consumption; $L h=$ husband's leisure; $L w=$ wife's leisure. Consumption consists of two items purchased on the market $(\mathrm{Xm})$ and goods produced in the home, either by the husband $(\mathrm{Zh})$, or by the wife $(\mathrm{ZW})$, thus:

$$
X=X m+Z h+Z W
$$

While the husband's production function is as follow:

$$
\mathrm{Zh}=\mathrm{f}(\mathrm{ahX} \mathrm{z}, \mathrm{Ph})
$$

where: ahxz $=$ fraction of market-goods purchased and used for the home production, $\mathrm{Ph}=$ hour devoted to household production. The wife's production function is analogous as follows:

$$
Z w=g(a w X z, P W)
$$

Economic Value Calculation Method of Housework. Activities of work at home should have a marketable value and need to be taken into account in order to be included in the calculation of national income, although for the measurement of quantity or quality is relatively difficult (Guhardja \& Hastuti, 1992). Each treatment types of unpaid work activities and their influencing factors, will determine the resulting product both tangible and intangible. The resulting product is estimated from the wage rate per hour. Market wage rate as the right size for impartial cost of hour working at home. Impartial costs every hour is the same for all the hours of paid work and also unpaid (Becker 1965; Bonke \& Weser 2004; Deding \& Lausten 2004).

Impartial cost is used as an approach because it is relatively difficult to determine the market price equivalent (Juster and Stafford 1985). Measurement of market economy of the value of goods or services is calculated with the price at the time of transaction, while for the sector of non-market because there is no transaction so there is no price and economic value. Economic evaluation of non market in general under the market value, with assuming time spent on unpaid activities and paid activities are perfect substitutes (Goldschmidt \& Clermont 1983) and result that is perceived by individual. Calculation of economic value is based on the assumption that the time spent on housework of unpaid and paid, subtitute perfectly. 
The economic value of housework is calculated as the product of use time for housework and housework shadow price estimated from the wage rate per hour. Market wage rate as the right size for impartial cost of hour working at home. Impartial cost every hour is the same for all the hours of work that paid and unpaid (Becker, 1965; Bonke, 2002; Deding \& Lausten, 2004). Impartial cost is used as an approach, because it is difficult to determine the market price equivalent (Juster and Stafford, 1985).

Research Hypothesis. Household characteristics (wife's age, husband's age, number of family members, wife's education and husband's education) have an effect on the economic value of housework on household income.

\section{METHODS OF RESEARCH}

The sample used this research is the core household is complete (whole) consisting of husband, wife, and children. The extensive of sampling research are households in 16 subdistricts of Palembang City, the capital of Sumatra Selatan Province, Indonesia. The sample collection procedure is to Proportionate Stratified Random Sampling. This technique is used when population has members/elements that are heterogeneous and stratified proportional (Sugiyono, 2015). The sample selection will start from the selection of sub-district, in stages subsequent to selection of villages, and then determining the amount of Neighborhood and the last determining the number of families to be visited when distributing the questionnaire. The data used in this study are primary data. The data are obtained through interviews with the aid of a questionnaire. Therefore, the data to be processed is a ratio scale and there is a dummy variable, so the validity and reliability of questionnaire research are not done. To answer the problem formulation of research, this study will analyze the data that had been collected statistically and in descriptive.

Statistically analysis is used to see what characteristics of households represented by number of family members, education of husband and wife and age of husband and wife have the effect on the economic value of housework on household income, while the descriptive analysis is used to describe the condition of the economic value of homework in Palembang City.

Regression analysis is a statistical method that can explain the functional relationships between the variables stated in a model or equation (Puspowarsito, 2008). Regression analysis, used to answer the third question of problem in this research, which is to determine the influence of household characteristics on the contribution of household income in Palembang city. Variable household characteristics are: wife's age (X1), wife's education (X2), husband's age (X3), husband's education (X4), number of family members (X5) and $Y$ is household income and the linear regression equation as follows:

$$
Y i j=\beta 0+\beta 1 X 1+\beta 2 X 2+\beta 3 X 3+\beta 4 X 4+\beta 5 X 5 D+e
$$

\section{FINDINGS AND DISCUSSION}

The Economic Value of Housework Generated by Wife In Palembang City. Table 1 shows that the time allocation of wife's work based on the sub-districts shows that the SubDistrict of Sukarame has allocation of wife disgorging time is higher than other sub-districts.

The results shows that the time of housework allocated by wife, an average of about eleven hours per day. Wife time allocation for housework is greater when presence of toddler compared to no toddler. Table 2 shows that the supplying meal consumption, clothing care, and housekeeping are allocated quite a lot in the housework that is done by wife. While the school age child care, time allocation of wife work is about the same time. Therefore, this research is households that have toddler, school age child or teens age child, so when viewed from 2, it seems differences in the time allocation of wife who does not have a toddler dominant more in teen-aged child care, while having a toddler is more dominant to care toddler. The results of this research support the research of Wahini (2012), which shows the allocation of child care in the teen-aged child is most in urban than rural areas. Thus it can be 
said that wife in urban areas have more attention towards the teen-aged child, due to a lifestyle that is individualist and intercourse of teen-aged child in urban worrying enough so that wife needs a lot more time to educate teen-aged child. Child care will be allocated different because every household has a special way of caring, nurturing and educating their children. This activity requires special handling more than tasks of other household. Child care providers are still dominant woman because the first relationship in the life of a child at birth is mother. In past, even woman choose to stop working just to care for their own children (Hersch, 2000).

Table 1 - Time Allocation of Wife Work Based on Sub-District

\begin{tabular}{|l|c|c|c|c|c|c|c|c|c|}
\hline \multirow{2}{*}{ Housework } & \multicolumn{7}{|c|}{ Sub-Districts } & Total \\
\cline { 2 - 10 } & $\begin{array}{c}\text { Alang2 } \\
\text { Lebar }\end{array}$ & $\begin{array}{c}\text { Bukit } \\
\text { Kecil }\end{array}$ & Kalidoni & $\begin{array}{c}\text { Kemu } \\
\text { ning }\end{array}$ & Sako & $\begin{array}{c}\text { Sematang } \\
\text { Borang }\end{array}$ & $\begin{array}{c}\text { Suka } \\
\text { Rame }\end{array}$ & Plaju & \\
\hline $\begin{array}{l}\text { Supplying } \\
\text { consumption }\end{array}$ & 148,83 & 148,39 & 158,20 & 174,35 & 140,34 & 183,21 & 164,80 & 170,59 & 160,75 \\
\hline Clothes Care & 164,55 & 157,20 & 176,55 & 171,67 & 160,51 & 207,95 & 168,45 & 176,37 & 171,50 \\
\hline Housekeeping & 106,68 & 126,32 & 147,01 & 114,83 & 125,27 & 147,56 & 110,73 & 126,54 & 124,30 \\
\hline Toddler Care & 77,53 & 21,78 & 64,05 & 45,37 & 67,20 & 42,97 & 41,11 & 50,04 & 52,08 \\
\hline School Age Child Care & 96,12 & 101,88 & 90,51 & 78,29 & 75,75 & 80,00 & 105,91 & 108,34 & 94,77 \\
\hline Teen-aged Child Care & 67,40 & 68,14 & 59,18 & 58,67 & 82,80 & 57,05 & 154,61 & 99,58 & 88 \\
\hline $\begin{array}{l}\text { Total Housework } \\
\text { (Minutes / Day) }\end{array}$ & 661,10 & 623,71 & 695,48 & 643,17 & 651,86 & 718,74 & 745,61 & 731,46 & 691,4 \\
\hline $\begin{array}{l}\text { Total Housework } \\
\text { (Hours / Day) }\end{array}$ & 11,02 & 10,40 & 11,59 & 11 & 11 & 12 & 12,43 & 12,19 & 11,52 \\
\hline
\end{tabular}

Source: Research Findings, 2015.

Table 2 - Time Allocation of wife Work with Attendance of Toddler

\begin{tabular}{|l|l|l|l|}
\hline \multirow{2}{*}{ Housework } & \multicolumn{2}{c|}{ Toddler? } & \multirow{2}{*}{ Total } \\
\cline { 2 - 4 } & \multicolumn{1}{|c|}{ No Toddler } & \multicolumn{1}{c|}{ Presence of Toddler } & \\
\hline Supplying consumption & 168,61 & 150,80 & 160,75 \\
\hline Clothes Care & 171,95 & 171,64 & 171,5 \\
\hline Housekeeping & 122,17 & 126,58 & 124,3 \\
\hline Toddler Care & - & 117,44 & 52,08 \\
\hline School Age Child Care & 92,79 & 98,35 & 94,77 \\
\hline Teen-Aged Child Care & 127,26 & 39,27 & 88 \\
\hline Total Housework (Minutes/Day) & 682,78 & 704,08 & 691,4 \\
\hline Total Housework (Hours/Day) & 11,38 & 11,73 & 11,52 \\
\hline
\end{tabular}

Source: Research Findings, 2015.

The allocation of housework in households that do not have toddler is fewer than have toddler. Time for child care allocated is fewest but the longest time to fix the food consumption and clothing care.

This is because the child is growing up, therefore her time is shifted to the fixing of food consumption and clothing care. This is in line with the statement of White (1984), revealed that the greater the age of the child, the more time spent to do the other work of household. Therefore, households who have toddler will spend more time at home, compared with households that do not have toddler. 
Table 3 - Characteristic Factors of Households that have effect on Contribution of Economic Value of Housework of Household Income In Palembang City

\begin{tabular}{|c|c|c|c|}
\hline \multirow{2}{*}{ Variabele factors } & \multicolumn{3}{|c|}{ Characteristic of Household } \\
\hline & $\beta$ & $t$ & Sig \\
\hline (Constant) & 198.035 & 16.521 & 0.000 \\
\hline Wife's age (X1) & -0.167 & -1.965 & 0.050 \\
\hline Wife's education (X2) & -0.088 & -1.917 & 0.056 \\
\hline Husband's age (X3) & 0.184 & 2.200 & 0.028 \\
\hline Husband's education (X4) & -0.033 & -0.656 & 0.512 \\
\hline Number of family members (X5) & -0.582 & -15.259 & 0.000 \\
\hline $\mathrm{R}$ & \multicolumn{3}{|c|}{0.629} \\
\hline R Square & \multicolumn{3}{|c|}{0.396} \\
\hline Adjusted $R$ Square & \multicolumn{3}{|c|}{0.380} \\
\hline $\mathrm{Df}$ & \multicolumn{3}{|c|}{15} \\
\hline F-hit & \multicolumn{3}{|c|}{25.605} \\
\hline Sig & \multicolumn{3}{|c|}{0.000} \\
\hline
\end{tabular}

Source: Research Findings, 2015.

An inferential analysis is conducted to determine which variable have effect on the contribution of economic value of housework on household income in Palembang city. The results of regression equation is as follow:

$$
Y i j=198.035-0.167 X 1-0.088 X 2+0.184 X 3-0.033 X 4-0.582 \times 15
$$

The results showed that wife's age, husband's age and number of family members have significantly effect on the economic value of housework on household income.

\section{SUGGESTIONS}

Based on the results and discussion, there are some suggestions that the authors propose as follows: the Government should consider the possibility of household production value into the calculation of local income even national income; for further research, suggested to do in-depth research (indepth interview and focus group discussion) by combining quantitative and qualitative methods. Besides that inserting socio-cultural variables in the research; for the community, this research could change public perception and give reward for wife's housework.

\section{REFERENCES}

1. Arboleda H. 1999. Valuation of Unpaid Work in Household Production and Volunteer Services. Bangkok, Thailand: ESCAP.

2. Becker, Gary. 1965. A Theory of the Allocation of Time. The Econ. Journal, 75: 493- 517.

3. Bennett L. 1983. An Approach To The Study Of Women's Productive Role As A Determinant Of Intra-Household Allocation Patterns.

4. Bonke, J. 2002. Paid Work and Unpaid Work: Diary Information Versus Questionnaire Information, 'Paper Presented at the Conference Of The International Association For Time Use Research, Lisbon, 16-18 October.

5. Bonke, J. \& Koch-Weser. 2004. The Welfare State and Time Allocation in Sweden, Denmark, France and Italy. In Janet Zollinger Giele and Elke Holst (eds.), «Changing life patterns in Western Industrial Societies». Elsevier, JAI, 2004.

6. Bryant, W. 1990. The Economic Organization Of The Household. Cambridge University Press; New York Port Chester Melbourne Sydney. 
7. Champ, P., Boyle, K., Brown, T. 2003. The Economics of non-market goods and resources a primer on nonmarket valuation. Netherlands: Kluwer Axademic Publishers.

8. Couprie. 2002. Alocation Of Time Within The Family: Are Single-Living Women Better Of Than Women In Couple. http:///www.eco.rug.n/.

9. Deding M \& Lausten M. 2004. Choosing Between His Time And Her Time? Market Work And Housework Of Danish Couples. http://www.sfi.dk/.

10. Donald, Stephen G. \& Hamermesh, Daniel S. 2009. A Structural Model of the Fixed Time Costs of Market Work, Economics Letters, September 2009, v. 104, iss. 3, pp. 125-28.

11. Ehrenberg, Ronald G, Robert S. Smith, 2000. «Modern Labor Economic». Seventh Edition, Addison Wesley Longman, Inc. USA.

12. Frazis, Harley dan Jay Stewart. 2009. How Does Household Production Affect Measured Income Inequality? Discussion Paper. IZA. No. 4048.

13. Gauger W, Walker K. 1980. The Dollar Value Of Household Work (Information Bulletin No.60, Revised). Ithaca: Cornell University, New York State College of Human Ecology.

14. Goldschmidt L, Clermont. 1983. Output-Related Evaluations Of Unpaid Household Work : A Challenge For Time Use Studies. Home Economics Research Journal, Vol: 12, No. 2.

15. Green M. 2003. Household's Unpaid Work By Immigration Status In Canada. [tesis]. Canada: University of Saskatchewan, Saskatoon.

16. Gronau, Reuben. 1977. Leisure, Home Production, and Work - the Theory of the Allocation of Time Revisited. Journal of Political Economy, 85(6), pp. 1099-1123.

17. Gronau, Reuben. 1980. Home Production--A Forgotten Industry. Review of Economics and Statistics 62:408-415.

18. Gronau, Reuben. 1986. Home Production -- A Survey. in Handbook of Labor Economics edited by Orley Ashenfelter and Richard Layard. Amsterdam, North Holland.

19. Heckman, James. 1974. Life Cycle Consumption and Labor Supply: An Explanation of the Relationship Between Income and Consumption Over the Life Cycle. American Economic Review, 1974, vol. 64, issue 1, pages 188-94.

20. Herbert H. Clark, Gregory L. Murphy. 1982. Advances in Psychology. Vol. 9, pp. 1-358. Language and Comprehension Edited by Jean-François Le Ny and Walter Kintsch.

21. Hersch J, Stratton L. 2000. Housework And Wages. Discussion Paper No. 300. Cambridge: Harvard Law School.

22. Ironmonger D. 2001. Household Production And The Household Economy. Research Paper. Departement of Economics, The University of Melbourne.

23. Jenkins, S.P. et al 1996. Household income plus household production: the distribution of extended income in the UK, Review of Income and Wealth, 42(4), 401-409.

24. Juster, Thomas F, dan Frank P. Stafford. 1985. Time, Goods, and Well-being, Survey Research Center Institute for Social Research. USA: The University Michigan.

25. Murphy, Martin. 1978. The Value of Nonmarket Household Production: Opportunity Cost Versus Market Cost Estimates. The Review of Income and Wealth 24:243-256.

26. Puspowartito, 2008. Metode Penelitian Organisasi dengan Aplikasi Program SPSS. Humaniora, Bandung.

27. Pylkkanen E. 2002. Productivity Of The Home Sector, An Application To Two- Earner Swedish Households. Journal of Political Economic.

28. Robeyns I. 2000. The Political Economy Of Market Work. http://www.fineprint.com.

29. Rochaeni S. et al, 2005. Faktor-Faktor Yang Mempengaruhi Keputusan Ekonomi Rumah Tangga Petani di Kelurahan Setugede Kota Bogor. Jurnal Agro ekonomi 23[2]: 133-158.

30. Sugiyono. 2015. Statistika untuk Penelitian. Alpabeta. Bandung.

31. Tarmizi, Nurlina. 2002. Ekonomi Ketenagakerjaan. Unsri Press: Palembang.

32. Wahini, Meda. 2012. Nilai Ekonomi dan Non Ekonomi Pekerjaan Rumah tangga Istri. Disertasi. Institut Pertanian Bogor.

33. White B. 1984. Measuring Time Allocation, Decision-Making And Agronomi Changes Affecting Rural Women: Examples From Recent Research In Indonesia.

34. Zick C, Bryant K. 1983. Alternative Strategies For Pricing Home Work Time. Home Economics Research Journal, Vol:12, No.2. 